\title{
Feeding patterns in Eubranchipus grubii (Dybowski 1860) (Branchiopoda: Anostraca) and its potential influence on the phytoplankton communities of vernal pools
}

\author{
Sofia CELEWICZ, ${ }^{1}$ Michał Jan CZYŻ, ${ }^{2}$ Bartłomiej GOŁDYN ${ }^{3 *}$ \\ ${ }^{1}$ Department of Botany, Poznan University of Life Sciences, Wojska Polskiego 71 C, 60-625 Poznań; ${ }^{2}$ Research Centre of Quarantine, \\ Invasive and Genetically Modified Organisms, Institute of Plant Protection - National Research Institute, Węgorka 20, 60-318 Poznań; \\ ${ }^{3}$ Department of General Zoology, Faculty of Biology, Adam Mickiewicz University in Poznań, 61-614 Poznań, Poland \\ *Corresponding author: glodny@amu.edu.pl
}

\begin{abstract}
Filtration patterns in the fairy shrimp Eubranchipus grubii were analysed under laboratory conditions using water containing phytoplankton from their actual locality in western Poland. After 48 hours of feeding, we compared the structure of algal communities in water samples in treatments with males, females and control. The mean filtration rate for $E$. grubii was relatively high $\left(14,488 \mathrm{~mL} \mathrm{~h}^{-1}\right)$ in comparison to other crustacean filter feeders and was higher for females than for males. Fairy shrimps grazed effectively on all 11 dominant phytoplankton taxa and there was no sign of overall preferences with regard to taxon, cell volume, length or shape. Female fairy shrimps removed significantly more cells of three taxa (Cryptomonas erosa, C. ovata and Trachelomonas volvocina). The differences between sexes did not depend on the cell volume or length of particular phytoplankton taxa but were significantly related to their initial abundance, initial biomass and shape. The higher the abundance and biomass of the algal taxa, the more intensively it was grazed by females than by males. Females were also observed to graze more on spherical and elongated cells. In conclusion, our results show E. grubii to be an effective, generalist filter feeder capable of significantly influencing the phytoplankton community of a vernal pool. Possible implications of such grazing pressure are also discussed.
\end{abstract}

Key words: Microalgae; fairy shrimp; temporary ponds; euglenoids; cryptophytes; chlorophytes.

Received: September 2017. Accepted: February 2018.

\section{INTRODUCTION}

Temporary ponds are usually small and shallow water bodies with a recurrent dry period of varying length (Williams, 2006). These ecosystems are especially interesting due to their fast responses to the environmental changes (Gołdyn et al., 2015a, 2015b; Kollár et al., 2015). They play important roles in the landscape such as flood control, ground water recharge, toxicant removal and recycling of nutrients (Waterkeyn et al., 2008). Because of their small size and the drying cycle, they are characterized with a much higher fluctuation of abiotic (physical and chemical) factors in comparison to larger aquatic ecosystems (Seminara et al., 2015). Such variable conditions in this type of ponds, both on a diurnal and seasonal time scale, create stressful habitats for aquatic organisms (Heilmeier et al., 2005). Consequently, temporary water bodies are inhabited by species with broad tolerances for physical and chemical factors (Arle, 2002) with a lifecycle that allows survival through the dry period or recolonization after inundation (Blanco et al., 2013).

Phytoplankton is a critical component in ecosystems of temporary waters and plays a major role in their functioning (Zongo and Zongo, 2016). In a ponds food web, it sustains an array of filtrators, which in turn are consumed by larger invertebrates and eventually vertebrates such as fish, amphibians and birds. In astatic and temporary ponds, the structure of phytoplankton communities can vary largely with respect to temporal and spatial or environmental differences. The major factors influencing this variability are related to water chemistry, catchment type, vegetation and microhabitat structure, predation and food web functioning (Reynolds, 2006, Boven et al., 2008; Celewicz-Gołdyn and Kuczyńska-Kippen, 2008; Celewicz-Gołdyn et al., 2008).

Among the temporal differences, changes observed in natural phytoplankton communities were usually associated with phenology of particular species or systematic groups related to different preferences towards temperature and underwater light climate (Kawecka and Eloranta, 1994; Reynolds, 1984; Calijuri et al., 2002). Connections between environmental and temporal factors have been largely ignored and very little is known on the dependence of shifts in phytoplankton communities in relation to changes in ecosystem functioning depending on time. An indirect connection between seasonality and structure of phytoplankton communities is the response 
of algal communities to fluctuations in populations of filter feeders. Seasonal changes in filter feeding zooplankton communities and their relation with phytoplankton structure have been well described for lake ecosystems (Reynolds, 2006; Vanderstukken et al., 2010; De Senerpont Domis et al., 2013), but such data are scarce for temporary ponds.

One of the most typical animal flagship groups of temporary waters are the large branchiopod crustaceans. Among them filter feeding fairy shrimps (Anostraca) occur often in great abundances and are considered as indicators of the best preserved temporary pools (Lumbreras et al., 2016). These abundant populations make them one of the most important components of such ecosystems. Their significance has been usually regarded from the perspective of predator-prey interactions, considering Anostraca as one of the most important food sources for predatory invertebrates (De Roeck et al., 2005; Ewald et al., 2013), amphibians (Ghioca-Robrecht and Smith, 2008; Ledón-Rettig et al., 2009) and birds (Green et al., 2005; Bogiatto and Karnegis, 2006; Horváth et al., 2013) of temporary waterbodies.

Nearly all fairy shrimp species are filter feeders, foraging mainly on phytoplankton as well as on bacteria and fungi suspended in the water column (some species are known to feed on zooplankton as well). Portions of their leaf-like legs are equipped with long setae and used as effective filtration apparatus (Dumont and Negrea, 2002). As opposed to zooplankton filtrators like cladocerans and some copepods, Anostraca have large bodies - up to $30 \mathrm{~mm}$ long or even more in some exceptionally large species - and thus their filtration capacity should be much higher. Their influence on communities of phytoplankton is moreover pronounced by their periodical mass occurrences, usually at the beginning of the inundation period (Williams, 2006).

Surprisingly, little is known on the influence of Anostraca on phytoplankton communities of temporary waters and all of the research on this subject comes from the arid environments and polar or alpine zones. In solar evaporation ponds in the Mojave Desert, Herbst (2006) found that the abundance of Artemia franciscana Kellogg, 1906 controls algal density and prevents the occurrence of algal blooms. No such relation however was observed by Naceur et al. (2011) for Artemia salina (Linnaeus, 1758) in Tunisia. Similarly, Brostoff et al. (2010) in clay pans of the Mojave Desert found no evidence for the influence of four large branchiopod species (including two species of Anostraca: Branchinecta mackini Dexter, 1956 and Branchinecta gigas Lynch, 1937) on chlorophyll content or algal species composition. In Antarctic South Orkney Islands ponds, Hawes (1985) found Branchinecta gaini Daday, 1910 largely controlled phytoplankton blooms. In the case of the Canadian Arctic,
Bertilsson et al. (2003) showed significant negative impact of Branchinecta sp. on bacterial and algal abundances, although this relation was lower than in the case of the cladoceran Daphnia sp. In a field experiment conducted in alpine ponds of Canadian Rockies, Vinebrooke et al. (2014) showed Branchinecta paludosa (O.F. Müller, 1788) effectively supresses phytoplankton response to nutrient enrichment. No such data are known for the temporary waters of temperate climate zone, however during our recent field study we have found significant differences in phytoplankton communities of ponds with and without the occurrence of the anostracan Eubranchipus grubii (Dybowski, 1860).

This finding led us to the present study, where we experimentally assess the feeding pattern of E. grubii using water containing the algal community from their actual habitat. Following our field observations, we assume that the influence of the fairy shrimp on phytoplankton will be high and that some groups of algae (presumably the biggest species) will be grazed upon more intensively than others. We hypothesise that there will be visible differences in feeding pattern between $E$. grubii females and males, reflecting sex-specific resource allocation (e.g. difference in resources needed to metabolise carotenoids; Gilchrist, 1968).

\section{METHODS}

Animals for the experiment were collected in late March from a small (surface ca $250 \mathrm{~m}^{2}$, maximum depth ca $100 \mathrm{~cm}$ ) vernal pool surrounded by mixed deciduous forest near Napachanie, western Poland ( $52^{\circ} 29^{\prime} 00^{\prime \prime} \mathrm{N}$; $\left.16^{\circ} 44^{\prime} 32^{\prime \prime} \mathrm{E}\right)$. The abundance of $E$. grubii was low during the sampling and did not exceed one individual per $20 \mathrm{~L}$. While sampling for the fairy shrimps, $10 \mathrm{~L}$ of water was also collected from the pond. In total, 30 individuals were collected (15 male and 15 female), all of them were adult with an average body length of $17.4 \mathrm{~mm}(\mathrm{SD}=0.91)$ for males and $15.9 \mathrm{~mm}(\mathrm{SD}=0.73)$ for females. After transporting to the laboratory, animals were placed in well-aerated tap water, in a cooling room $\left(4^{\circ} \mathrm{C}\right)$ for three hours, to enable defecation and cleaning of filtration apparatus. Water from the pond was strained using a net of $300 \mu \mathrm{m}$ mesh to remove crustacean zooplankton (mainly Cladocera and Copepoda). Occurrence of smaller fractions of zooplankton is far less stochastic in early spring samples from vernal pools of the region according to our preliminary observations. Therefore, we assume their abundance was similar in all the treatments of our experiment and they did not influence the results significantly.

Each of the fairy shrimps were then placed in $200 \mathrm{~mL}$ of the pond water and stored in the cooling room again, under 12/12 hours photoperiod. The volume of water per 
each animal used in our experiment reflected the upper abundances of E. grubii recorded during our long-term study on other vernal pools. In addition to the 30 containers with the female and male fairy shrimps, another 15 containers with pond water without animals were also prepared as a control. All the containers were placed open on the same shelf arranged in a checkerboard pattern (containers with the same contents were not neighbouring). The water was stirred every few hours to prevent the phytoplankton from sedimenting on the bottom of the containers.

After $48 \mathrm{~h}$ the animals were removed, the water was stirred again and a $10 \mathrm{~mL}$ sample was collected from each container. Samples of phytoplankton were fixed with Lugol solution. Algae composition and abundance was analysed using a light microscope. The specimens were counted in a Sedgwick-Rafter chamber of a volume of $0.67 \mathrm{~mL}$. The same methodology of phytoplankton analysis was also applied to a subsample of the pond water which was not used in the experiment but was preserved right after transporting to the laboratory and after removing crustacean zooplankton. Algae were determined to species (in most cases) or genus (four taxa) level. Furthermore, biomass of each species was calculated following Hutorowicz (2009) and each species was assigned to one of three shape groups: elongate, elliptical or spherical. To enable general comparisons with literature data on other anostracan species, ingestion and filtration rates were calculated following Brendonck (1993b).

Data on the abundance of algae in containers without animals were treated as control, while phytoplankton counts before the experiments were used as a reference. The data were processed using Generalized Linear Mixed Models (GLMM) with log-link and Poisson error distributions. Numbering or biomass of particular phytoplankton species in the samples after the experiment was used as dependent variable and experimental treatments (male, female and control) crossed with algal species or shape groups as a fixed factor. To reduce the stochastic effect of rare species on the results of the analyses, only the data on the most frequent algae (found in at least 10 experimental treatments) were used in the model (11 species in total; these were also all the dominant species, covering more than $98 \%$ of the phytoplankton community in terms of abundance and biomass). Variable coding for each sample was used to code blocks of data with nested measurements for particular species. The analyses were focused on between factor effects with Fisher's Least Significant Difference (LSD) test. Models were checked for over-dispersion by extracting Pearson residuals. Calculations were performed using IBM SPSS Statistics 24 software, values of $\mathrm{P}<0.05$ were considered as significant.

To check if there is any relation between the filtration rate for particular algae species and their primary abundance or cell size, contrasts from the GLMM were extracted for each species. They were then checked for correlation with their cell volume, abundance and biomass in the reference sample using Ordinary Least Squares regression with randomization test $(10,000$ randomizations). This was performed in RundomPro 3.14 software. The data were log-transformed before the analyses to obtain normal distributions of the resulting tests statistics.

\section{RESULTS}

In the reference sample of water collected from the pond, 36 taxa of phytoplankton from six taxonomic groups were found: cyanobacteria (2 taxa), chlorophytes (11), diatoms (8), euglenophytes (3), cryptophytes (10) and dinophytes (2) (see Supplementary Tab. 1 for details). Total abundance of algae in the water before the experiment was 1421 cells $\mathrm{mL}^{-1}$.

Mean filtration rate for E. grubii recorded during the experiment was $14.49 \mathrm{~mL} \mathrm{~h}^{-1}$ and the mean ingestion rate was 3265.95 cells h$^{-1}$. Both indices were higher for females than for males (see Tab. 1 for details).

GLMM shows significant differences $(\mathrm{F}=60.654$; $\mathrm{P}<0.001)$ in the abundance of algae after the experiment when the control treatments were compared with female $(\mathrm{t}=10.574 ; \mathrm{P}<0.001)$ and male $(\mathrm{t}=8.742 ; \mathrm{P}<0.001) E$. grubii treatments as well as when males and females $(\mathrm{t}=3.434 ; \mathrm{P}=0.001$ ) were compared (Fig. 1). When the analysis was focused on the contrasts in abundances of particular taxa of phytoplankton, the model showed

Tab. 1. Filtration and ingestion rates for all individuals, males and females of $E$. grubii recorded during the experiment.

\begin{tabular}{llcccc} 
& & Mean & Min & Max & SD \\
Filtration rate (mL h-1) & All individuals & 14.488 & 2.24 & 22.62 & 4.7996 \\
& Females & 16.953 & 11.66 & 22.62 & 3.0807 \\
& Males & 12.023 & 2.24 & 20.69 & 4.9428 \\
\hline Ingestion rate (cells h-1) & All individuals & 3265.954 & 1456.44 & 3487.89 & 406.7823 \\
& Females & 3424.473 & 3289.89 & 3487.89 & 61.5169 \\
& Males & 3107.434 & 1456.44 & 3478.84 & 526.2151 \\
\hline
\end{tabular}


significant differences for all 11 algae (Tab. 2). In the case of all taxa the abundance was significantly higher in control group than in female or male treatments. Significant differences between male and female treatments were found in the case of Crypromonas erosa Ehrenberg 1832, Cryptomonas ovata Ehrenberg 1832 and Trachelomonas volvocina Ehrenberg 1834; the abundance

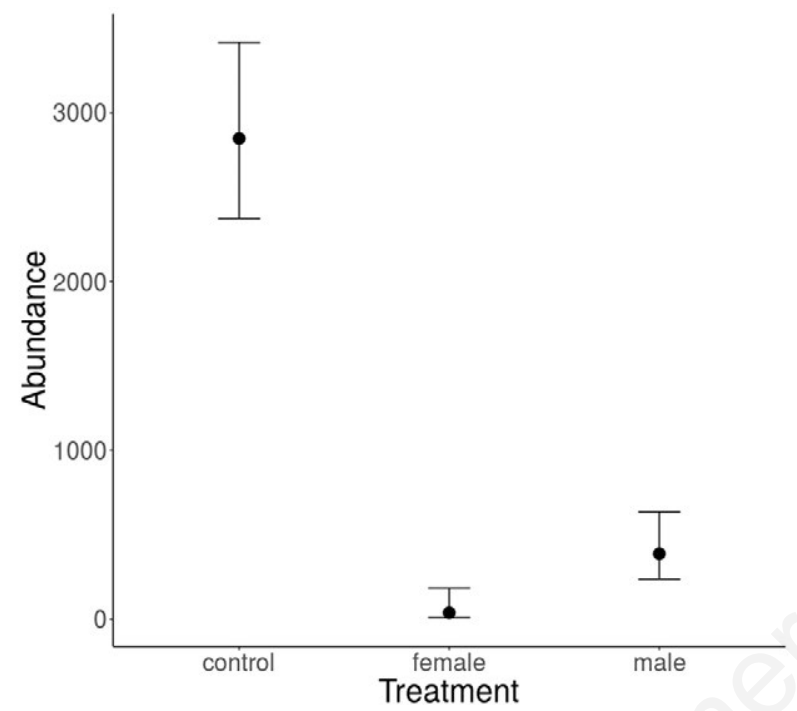

Fig. 1. Results of Generalized Linear Mixed Model on abundances of phytoplankton (cells $\mathrm{mL}^{-1}$ ) in particular treatments after the experiment (estimated means and 95\% Confidence Intervals). of these species was higher in the containers with male $E$. grubii. Additionally, for all of our shape groups the abundances were significantly higher in control than female and male treatments. In the case of elongate algae abundances, no differences between male and female samples were found; in contrast, spherical and elliptic phytoplankton taxa were grazed more intensively by females than by males.

When similar analysis for the data on biomass was performed ( $\mathrm{F}=23.899 ; \mathrm{P}<0.001)$, significant differences between the control and female $(\mathrm{t}=6.666 ; \mathrm{P}<0.001)$ as well as male $(\mathrm{t}=5.751 ; \mathrm{P}<0.001)$ treatments were found, however biomass of algae grazed by males versus females did not differ significantly according to the LSD test $(\mathrm{t}=1.962 ; \mathrm{P}=0.052)$ (Fig. 2). When the analysis focused on the contrasts in biomass of particular taxa of phytoplankton, the results were exactly the same as in the case of abundance, since the biomass was calculated by multiplication by constant values. However, when biomass of particular shape groups was compared, a significant difference for female versus male treatment was found only in the case of spherical species. Differences between control samples and male or female treatments were always significant with respect to biomass of particular shape groups (Tab. 2).

In both cases (males and females), grazing efficiency on particular algal taxa, measured as the size of GLMM contrasts between control and treatment did not depend significantly on the phytoplankton cell size or length but was significantly related to its initial abundance and biomass (see Tab. 3 for detailed test statistics). Similarly, observed differences between the feeding pattern in males

Tab. 2. Results of the Generalized Linear Mixed Models (GLMM) analysis with Fisher's Least Significant Difference (LSD) test on the differences in abundances of particular phytoplankton taxa and shape groups in particular treatments of the experiment.

\begin{tabular}{|c|c|c|c|c|c|c|c|c|}
\hline \multirow[b]{2}{*}{ Taxon / group } & \multicolumn{2}{|c|}{ General test } & \multicolumn{2}{|c|}{ Control vs male } & \multicolumn{2}{|c|}{ Control vs female } & \multicolumn{2}{|c|}{ Female us male } \\
\hline & F & $\mathbf{P}$ & $\mathrm{t}$ & $\mathbf{P}$ & $\mathrm{t}$ & $\mathbf{P}$ & $\mathrm{t}$ & $\mathbf{P}$ \\
\hline Chlorogonium sp. & 42.405 & $<0.001$ & 8.246 & $<0.001$ & 9.110 & $<0.001$ & 1.893 & 0.059 \\
\hline Chroomonas caudata & 12.052 & $<0.001$ & 4.501 & $<0.001$ & 4.882 & $<0.001$ & -0.861 & 0.390 \\
\hline Cryptomonas caudata & 13.300 & $<0.001$ & 3.876 & $<0.001$ & 4.959 & $<0.001$ & -1.738 & 0.083 \\
\hline Crypromonas erosa & 66.777 & $<0.001$ & 10.625 & $<0.001$ & 11.459 & $<0.001$ & -2.077 & 0.038 \\
\hline Cryptomonas marssonii & 24.501 & $<0.001$ & 5.983 & $<0.001$ & 6.878 & $<0.001$ & -1.735 & 0.083 \\
\hline Cryptomonas ovata & 10.243 & $<0.001$ & 2.462 & 0.014 & 4.027 & $<0.001$ & -2.157 & 0.031 \\
\hline Cryptomonas pyrenoidifera & 6.384 & 0.002 & 2.308 & 0.021 & 3.352 & 0.001 & -1.470 & 0.142 \\
\hline Cryptomonas rostrata & 5.875 & 0.003 & 2.857 & 0.004 & 3.338 & 0.001 & -0.937 & 0.350 \\
\hline Rhodomonas minuta & 6.433 & 0.002 & 2.821 & 0.005 & 3.437 & 0.001 & -1.140 & 0.255 \\
\hline Schroederia setigera & 16.492 & $<0.001$ & 5.032 & $<0.001$ & 5.624 & $<0.001$ & -1.357 & 0.175 \\
\hline Trachelomonas volvocina & 19.804 & $<0.001$ & 4.333 & $<0.001$ & 5.972 & $<0.001$ & -2.405 & 0.017 \\
\hline Elliptic (abundance) & 44.339 & $<0.001$ & 7.219 & $<0.001$ & 8.997 & $<0.001$ & -3.139 & 0.002 \\
\hline Elongate (abundance) & 17.498 & $<0.001$ & 5.178 & $<0.001$ & 5.795 & $<0.001$ & -1.392 & 0.164 \\
\hline Spherical (abundance) & 19.804 & $<0.001$ & 4.333 & $<0.001$ & 5.972 & $<0.001$ & -2.405 & 0.017 \\
\hline Elliptic (biomass) & 20.429 & $<0.001$ & 5.287 & $<0.001$ & 6.153 & $<0.001$ & -1.843 & 0.066 \\
\hline Elongate (biomass) & 16.496 & $<0.001$ & 5.032 & $<0.001$ & 5.624 & $<0.001$ & -1.358 & 0.175 \\
\hline Spherical (biomass) & 19.804 & $<0.001$ & 4.333 & $<0.001$ & 5.972 & $<0.001$ & -2.405 & 0.017 \\
\hline
\end{tabular}


and females did not depend on the cell volume or length of particular phytoplankton taxa, but was significantly related to their initial abundance and initial biomass. The higher abundance and biomass the algal taxon had, the more intensively it was grazed by females than by males.

\section{DISCUSSION}

The results of our study show that the impact of $E$. grubii on the algal communities is most of all of quantitative nature. We have found that the abundance of algae was significantly higher in control group than in female or male treatments and that the grazing efficiency was related primarily to initial abundance and biomass of particular phytoplankton taxa. Moreover, our experiment demonstrated strong differences in filtration intensity between the sexes in E. grubii with females removing more algal cells from the water column.

Since the aim of the present study was to check for the influence of E. grubii on the natural phytoplankton communities in the early stage of the hydroperiod of a vernal pool, we used water from the natural site with naturally low abundances of algae (Williams, 2006). This makes our results on filtration and digestion rates hard to compare with previous studies in other anostracan species. Most of the scarce literature on this subject comes for species typical for arid and semiarid climate zones (i.e., Artemia sp. and Dendrocephalus sp.). Moreover, in most cases these experiments aimed to determine the best feeding schemes for anostracan aquaculture and thus were usually conducted on only one species of algae tested in much higher concentrations than in our study. Consequently, most of the experiments conducted so far on adult fairy shrimps show lower filtration and higher ingestion rates than in our case (Brendonck, 1993b;
Evjemo et al., 2000; Da Costa et al., 2005; Brito et al., 2010), as typically filtration rate is negatively related to food concentration, whereas ingestion rate is positively related (Da Costa et al., 2005). Values of filtration rate similar to those found in our experiments were recorded in single treatments by $\mathrm{Da}$ Costa et al. (2005) and Brendonck (1993b) in the case of the lowest food concentrations applied in their experiments and by Riisgård et al. (2015). A maximum filtration rate much higher $\left(128.21 \mathrm{~mL} \mathrm{~h}^{-1}\right)$ than in the present study, however, was recorded by Brito et al. (2010) for Dendrocephalus spartaenovae Margalef, 1961, for the case of the

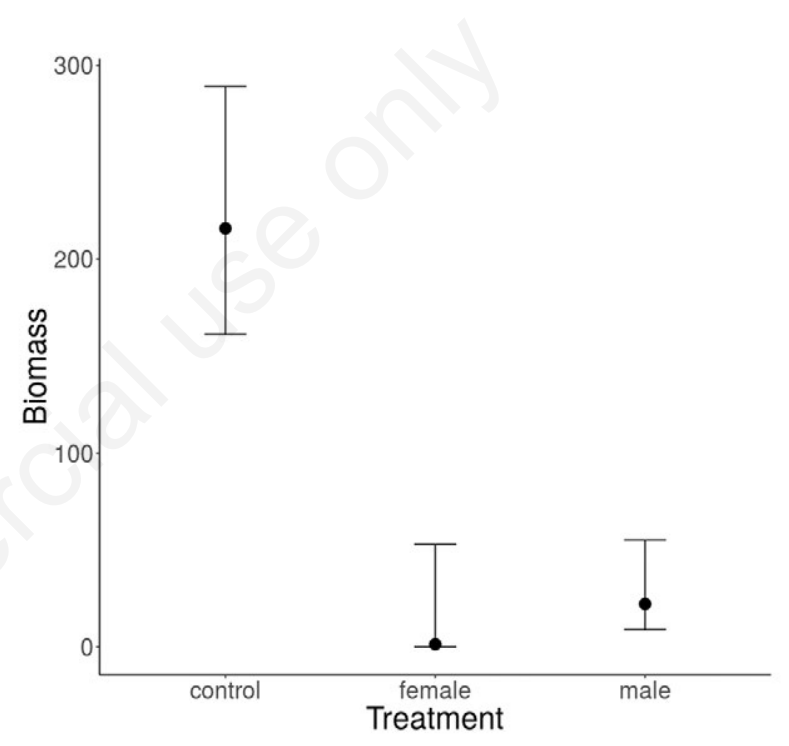

Fig. 2. Results of Generalized Linear Mixed Model on biomass of phytoplankton $\left(\mu \mathrm{m}^{3} \mathrm{~mL}^{-1}\right)$ in particular treatments after the experiment (estimated means and 95\% Confidence Intervals).

Tab. 3. Results of Ordinary Least Squares regression with randomization test on the contrasts from Generalized Linear Mixed Models (GLMM) comparing each treatment for particular species as dependent variables and variables describing each species as explanatory (performed on log transformed data).

\begin{tabular}{|c|c|c|c|c|}
\hline Dependent variable & Explanatory variable & $\mathbf{r}$ & SEE & $\mathbf{P}$ \\
\hline $\begin{array}{l}\text { Control vs male } \\
\text { GLMM contrasts }\end{array}$ & $\begin{array}{l}\text { Cell volume } \\
\text { Cell length } \\
\text { Initial abundance } \\
\text { Initial biomass }\end{array}$ & $\begin{array}{l}0.383 \\
0.088 \\
0.831 \\
0.821\end{array}$ & $\begin{array}{l}1.763 \\
1.901 \\
1.062 \\
1.088\end{array}$ & $\begin{array}{l}0.248 \\
0.801 \\
0.001 \\
0.001\end{array}$ \\
\hline $\begin{array}{l}\text { Control vs female } \\
\text { GLMM contrasts }\end{array}$ & $\begin{array}{l}\text { Cell volume } \\
\text { Cell length } \\
\text { Initial abundance } \\
\text { Initial biomass }\end{array}$ & $\begin{array}{l}0.409 \\
0.084 \\
0.845 \\
0.846\end{array}$ & $\begin{array}{l}1.706 \\
1.864 \\
1.000 \\
0.997\end{array}$ & $\begin{array}{l}0.213 \\
0.809 \\
0.002 \\
0.001\end{array}$ \\
\hline $\begin{array}{l}\text { Male } v s \text { female } \\
\text { GLMM contrasts }\end{array}$ & $\begin{array}{l}\text { Cell volume } \\
\text { Cell length } \\
\text { Initial abundance } \\
\text { Initial biomass }\end{array}$ & $\begin{array}{l}0.535 \\
0.036 \\
0.868 \\
0.931\end{array}$ & $\begin{array}{l}1.487 \\
1.760 \\
0.874 \\
0.641\end{array}$ & $\begin{array}{c}0.096 \\
0.922 \\
0.001 \\
<0.001\end{array}$ \\
\hline
\end{tabular}


treatment with the lowest concentration of algal cells $\left(10 \times 10^{3}\right.$ cells $\left.\mathrm{mL}^{-1}\right)$.

The problem of relation between shape and size of algal cells and grazing efficiency in Anostraca is absent from the literature. Such interference, however, was reported in some other planktonic filter feeders (Frost, 1972; Nival and Nival, 1976), with larger phytoplankton taxa being filtered more effectively. According to Gliwicz (1977) very small algal cells may slip though the filtering setae of zooplankton and thus be captured at a lower rate than larger algae. Levine et al. (1999) indicate that the optimal food size for most zooplankton is 10 to $20 \mu \mathrm{m}$. Such tendency towards selective feeding on larger algal cells seems to be an energetically efficient strategy. As such, it is very likely to be universal across crustacean filter feeders including fairy shrimps, even though they are much larger than the zooplankton species studied so far in this respect.

Indeed, in our experiment the taxa grazed with the highest efficiency according to GLMM contrasts (Chlorogonium sp., T. volvocina and C. erosa) had a cell size length between 17 and $30 \mu \mathrm{m}$, fitting into the abovementioned size range. Also the smallest sized species, Rhodomonas minuta Skuja $1948(8 \mu \mathrm{m})$ and Chroomonas caudata Geitler $1924(12 \mu \mathrm{m})$, seemed to be grazed with lower efficiency than most of the remaining phytoplankton taxa. On the other hand, the species with the longest cells in our experiment was Schroederia setigera (Schröder 1897) $(98 \mu \mathrm{m})$, but the GLMM contrasts for this species were only slightly higher than in the case of the two smallest species. Moreover, the statistical analyses show that there was no relation between the algal cell length, size or shape and the abundance and biomass of phytoplankton after the experiment in control vs male or control vs female treatments.

The significant relationship between the grazing efficiency and initial abundance and biomass of particular taxa recorded in our study is typical for filter feeding generalists (Peters and Downing, 1984). Such relationships could also be inferred from the previous studies on Anostraca where ingestion rates on several concentrations of one food type were tested (Brendonck, 1993b; Da Costa et al., 2005; Brito et al., 2010). These facts, connected with our results showing no sign of preference towards phytoplankton of any size or shape in E. grubii, indicate that this species should be considered a nonselective generalist. This is in accordance with conclusions from previous studies conducted on anostracan species from arid zones analyzing the contents of their digestive tracts (Bernice, 1971; Brendonck, 1993a).

Our experiments showed significant differences between the feeding pattern of males and females in $E$. grubii. In general, females had higher filtration and ingestion rates, when both phytoplankton abundance and biomass were compared. The differences were also visible on the level of particular phytoplankton taxa - three species (C. erosa, C. ovata and T. volvocina) were grazed more effectively by females than by males. These species belong to the four most abundant in our experiment and represent spherical and elongate taxa, and therefore the differences at taxa level are also reflected in our analyses of shape groups and initial abundance. However, when the biomass of particular shape groups was compared, significant differences for female versus male treatments were found only in the case of spherical species. The difference in the case of spherical $T$. volvocina therefore seems to be the most interesting. This euglenoid species seems to be a less attractive food source for filter feeders because of its hard lorica covering the cell. Thus, the higher grazing rate by females shows that when sexes are compared the females are more generalist than the males. This conclusion, combined with the generally higher filtration and ingestion rates in females could be explained by their higher nutritional requirements connected with production of cysts. These highly specialised, encapsulated embryos are deposited by anostracan females in great amounts in the sediments of their temporary habitats and are able to survive long periods of drought and other unfavourable environmental conditions (Brendonck and De Meester, 2003).

Eubranchipus grubii is a relatively long-living species with lifespan exceeding 4 months under favourable weather conditions (Gołdyn et al., 2012). Moreover, females tend to have lower mortality and dominate the populations in later stages of their functioning (Gołdyn and Bernard, 2008). Observed differences in filtration rate might thus be also a sign of adaptation for longer lifespan under changing environmental conditions or could per se increase the female longevity.

Similar sexual differences in feeding pattern were found by Brendonck (1993b) and Ali et al. (1996) in Streptocephalus proboscideus (Frauenfeld, 1873), with female filtration and ingestion rates significantly higher than male. On the other hand, there were no significant differences in food intake between the sexes in neither Streptocephalus dichotomus (Bernice, 1971), nor in D. spartaenovae (Brito et al., 2010). Observed relationships are thus not universal across all Anostraca and could be related to different species-specific life history adaptations.

Our reference phytoplankton community collected from the actual locality of E. grubii was dominated by rstrategists, small-sized and short-lived algae (e.g., from the genera Cryptomonas, Chroomonas, Rhodomonas and Chlorogonium) and the number of taxa was low. Such structure of algal communities is generally typical for temporary waters, where the variation of environmental 
factors is high compared to permanent ponds (Collinson et al., 1995; Marrone et al., 2006; Cereghino et al., 2008). The most abundant algal taxa (e.g. Chlorogonium sp. and C. erosa) in the investigated freshwater ecosystem were stress tolerants, typical for unstable environments. Also the high occurrence of $T$. volvocina in our reference sample is certainly due to the fact that this species, among other euglenophytes, is able to encyst during unfavourable conditions such as drought periods (Zongo and Zongo, 2016) and frequently occurs in temporary ponds. Furthermore, all the dominant taxa (especially the cryptophytes and single celled chlorophytes) present in the samples belong to the groups regarded as a food of high nutritional quality for many zooplankton species (Hunt and Matveev, 2005; von Rückert and Giani, 2008). High grazing pressure from E. grubii is therefore an additional factor, enhancing the influence of harsh environmental conditions on the overall structure of the algal community.

Our findings show that if the population of E. grubii in the temporary pond is abundant, it can significantly shape the phytoplankton structure. Since the filtration rate is high and all the dominant taxa of phytoplankton are removed efficiently from the water column, grazing pressure of E. grubii promotes the development of fastgrowing single-celled r-strategists. This fact might explain relations observed in the field, where phytoplankton communities of astatic ponds where these fairy shrimps are present or absent differ sizably, even despite great similarity of the ponds and their small spatial segregation.

This modulatory effect of abundant filter-feeder population is crucial for the future shape of the phytoplankton community, since it occurs in the nodal, early phase of its functioning. Occurrence of fairy shrimps in their temporary habitats is largely periodic and they are one of the textbook examples of animal groups passing obligatory developmental diapause during their life cycle (Brendonck and De Meester, 2003). Large amounts of cysts on the pond's bottom constitute so-called cyst bank and their future development depends on the occurrence of suitable environmental conditions in the habitat. When species-specific chemical properties occur in the water, mass hatching of larvae is observed and their growth is rapid, leading to maturity within weeks. In the majority of species, the lifespan of adult individuals is relatively short and lasts from one week to two months (Gołdyn et al., 2012). The next generation, and thus the next mass occurrence of large filter feeders in the pond, does not usually take place until the next inundation period occurs.

In E. grubii, as a typical vernal pool species, hatching events take place in a limited time frame - after the winter or early spring snow thawing. Moreover, hatching does not occur every year and is strongly related to the fluctuations of the water level in the pond; it was observed only in ponds that were at least partially dry during winter. Furthermore, the highest abundances of larvae were recorded in pools that were completely dry before the thawing. This leads to a situation where an abundant population of filter feeders develops in the ecosystem right after its restart following the winter/spring inundation. Effects of such one-time mass occurrence on the structure of developing phytoplankton communities should be prominent.

To some extent, each single inundation period of a temporary waterbody could be considered an occurrence of a new habitat, consisting of several empty ecological niches waiting for recolonization by specialized species (Williams, 2006). Sudden occurrence of water is thus a starting point for diapausing individuals of particular species for the race towards colonization of these niches and founding stable populations before the goal is achieved by competing species. Therefore, the short period following the inundation is one of the most critical for the future shape and fate of the community - at least until the next desiccation and inundation event after which the whole ecosystem is restarted based on diapausing spores from the preceding generations. In this period, occurrence of a strong limiting factor, like an abundant population of big and effective filter feeders, is an event which decides future community composition. Since planktonic algae are considered as one of most important components of the water ecosystems, such early start predestination seems crucial for the fate of the whole temporary ecosystem in a given inundation period, which could take years in some more permanent pools (Williams, 2006).

\section{CONCLUSIONS}

Temporary waters are often considered to be good models for research on processes related to diverse ecological problems, from colonization to metacommunity functioning (Williams, 2006). Our results suggest that such studies should consider the early history of the ecosystem among the factors used in modelling of their functioning, with a strong emphasis on the events occurring right after the inundation (De Meester et al., 2005). One of such important factors is the short (and thus easy to overlook) but mass occurrence of large invertebrate filter feeders, like the fairy shrimp E. grubii in our study. In this respect, deep knowledge on environmental factors triggering such mass occurrences is an important field for the future studies on functioning of temporary pools. These mechanisms are particularly interesting in the case of vernal pools of temperate climate, where they appear to be more sophisticated and complex than in the classical example of desert pools. 


\section{ACKNOWLEDGMENTS}

We are grateful to Piotr Zduniak for his advice on statistical analyses. Special thanks go to Christopher Hobbs and Abigail Horn for English corrections as well as for useful comments on the draft of the present paper. The research was partially supported by the Polish National Science Centre grant no. [DEC 2011/01/N/NZ8/03649] and by the Ministry of Science and Higher Education, Warsaw, Poland [statutory funds No 508.641.01].

\section{REFERENCES}

Ali AJ, Sarma SSS, Murugan G, Dumont HJ, 1996. Effect of zooplankton type and abundance on prey consumption by the fairy shrimp, Streptocephalus proboscideus (Anostraca: Crustacea). Hydrobiologia 319:191-202.

Arle J, 2002. Physical and chemical dynamics of temporary ponds on a calcareous plateau in Thuringia, Germany. Limnologica 32:83-101.

Bernice R, 1971. Food, feeding and digestion in Streptocephalus dichotomus Baird (Crustacea: Anostraca). Hydrobiologia 38:507-520.

Bertilsson S, Hansson L-A, Graneli W, Philibert A, 2003. Sizeselective predation on pelagic microorganisms in Arctic freshwaters. J. Plankton Res. 25:621-631.

Blanco S, Alvarez-Blanco IA, Cejudo-Figueiras C, Espejo JMR, Barrera CB, Becares E, Olmo FD, Artigas RC, 2013. The diatom flora in temporary ponds of Donana National Park (southwest Spain): five new taxa. Nord. J. Bot. 31:489-499.

Bogiatto RJ, Karnegis JD, 2006. The use of eastern Sacramento valley vernal pools by ducks. Calif. Fish. Game. 92:125-141.

Boven L, Stoks R, Forro L, Brendonck L, 2008. Seasonal dynamics in water quality and vegetation cover in temporary pools with variable hydroperiods in Kiskunsàg (Hungary). Wetlands 28:401-410.

Brendonck L, 1993a. Feeding in the fairy shrimp Streptocephalus proboscideus (Frauenfeld) (Brenchiopoda, Anostraca). I Aspects of the feeding biology. J. Crustacean Biol. 13:235-244.

Brendonck L, 1993b. Feeding in the fairy shrimp Streptocephalus proboscides (Frauenfeld) (Branchiopoda: Anostraca). II Influence of environmental conditions on feeding rate. J. Crustacean Biol. 13:236-244.

Brendonck L, De Meester L, 2003. Egg banks in freshwater zooplankton: evolutionary and ecological archives in the sediment. Hydrobiologia 491:65-84.

Brito D, Brito R, Pereira G, 2010. Evaluation of the filtration and ingestion rates of Dendrocephalus spartaenovae (Crustacea: Anostraca: Thamnocephalidae) with Pseudokirchneriella subcapita y Chlorella vulgaris in laboratory conditions. Interciencia 35:126-130.

Brostoff WN, Holmquist JG, Schmidt-Gengenbach J, Zimba PV, 2010. Fairy, tadpole, and clam shrimps (Branchiopoda) in seasonally inundated clay pans in the western Mojave Desert and effect on primary producers. Saline Systems 6:11.

Calijuri MC, Dos Santos ACA, Jati S, 2002. Temporal changes in phytoplankton community structure in a tropical and eutrophic reservoir Barra Bonita, S.P. - Brazil. J. Plankton Res. 24:617-634.

Celewicz-Gołdyn S, Kuczyńska-Kippen N, 2008. Spatial distribution of phytoplankton communities in a small water body. Botanika-Steciana 12:15-21.

Celewicz-Gołdyn S, Kuczyńska-Kippen N, Nagengast B, 2008. Phytoplankton community structure in two types (forest vs. field) of small water bodies. Botanika-Steciana 12:23-28.

Cereghino R, Biggs J, Oertli B, Declerck S, 2008. The ecology of European ponds: defining the characteristics of a neglected freshwater habitat. Hydrobiologia 597:1-6.

Collinson NH, Biggs J, Corfield A, Hodson MJ, Walker D, Whitfield M, Williams PJ, 1995. Temporary and permanent ponds: an assessment of the effects of drying out on the conservation value of aquatic macroinvertebrate communities. Biol. Conserv. 74:125-133.

Da Costa RAAM, Koening ML, Pereira LCC, 2005. Feeding adult of Artemia salina (Crustacea-Branchiopoda) on the dinoflagellate Gyrodinium corsicum (Gymnodiniales) and the Chryptophyta Rhodomonas baltica. Braz. Arch. Biol. Techn. 48:581-587.

De Meester L, Declerck S, Stoks R, Louette G, Van De Meutter F, De Bie T, Michels E, Brendonck L, 2005. Ponds and pools as model systems in conservation biology, ecology and evolutionary biology. Aquat. Conserv. 15:715-725.

De Roeck ERM, Artois T, Brendonck L, 2005. Consumptive and non-consumptive effects of turbellarian (Mesostoma sp.) predation on anostracans. Hydrobiologia 542:103-111.

De Senerpont Domis LN, Elser JJ, Gsell AS, Huszar VLM, Ibelings BW, Jeppesen E, Kosten S, Mooij WM, Roland F, Sommer U, Van Donk E, Winder M, Lürling M, 2013. Plankton dynamics under different climatic conditions in space and time. Freshwater Biol. 58:463-482.

Dumont HJ, Negrea S, 2002. Introduction to the class Branchiopoda. Guides to the microinvertebrates of the continental waters of the world. Backhuys, Leiden.

Evjemo JO, Vadstein O, Olsen Y, 2000. Feeding and assimilation kinetics of Artemia franciscana fed Isochrysis galbana (clone T. Iso). Mar. Biol. 136:1099-1109.

Ewald NC, Hartley SE, Stewart AJA, 2013. Climate change and trophic interactions in model temporary pond systems: The effects of high temperature on predation rate depend on prey size and density. Freshwater Biol. 58:2481-2493.

Frost BW, 1972. Effects of size and concentration of food particles on the feeding behavior of the marine planktonic copepod Calanus pacificus. Limnol. Oceanogr. 17:805-815.

Ghioca-Robrecht DM, Smith LM, 2008. Feeding ecology of polymorphic larval barred tiger salamanders in playas of the Southern Great Plains. Can. J. Zoo. 86:554-563.

Gilchrist B, 1968. Distribution and relative abundance of carotenoid pigments in Anostraca (Crustacea: Branchiopoda). Comp. Biochem. Physiol. 24:123-147.

Gliwicz M, 1977. Food size selection and seasonal succession of filter feeding zooplankton in an eutrophic lake. Ekol. Pol. 25:179-225

Gołdyn B, Bernard R, 2008. Preliminary data on the distribution and phenology of Eubranchipus grubii (Dybowski,1860) (Crustacea: Anostraca) in the Wielkopolska region. Annales UMCS (C) 63:23-29. 
Gołdyn B, Bernard R, Czyz MJ, Jankowiak A, 2012. Diversity and conservation status of large branchiopods (Crustacea) in ponds of western Poland. Limnologica 42:264-270.

Gołdyn B, Chudzińska M, Barałkiewicz D, Celewicz-Gołdyn S, 2015a. Heavy metal contents in the sediments of astatic ponds: Influence of geomorphology, hydroperiod, water chemistry and vegetation. Ecotox. Environ. Safe. 118:103-111.

Gołdyn B, Kowalczewska-Madura K, Celewicz-Gołdyn S, 2015b. Drought and deluge: Influence of environmental factors on water quality of kettle holes in two subsequent years with different precipitation Limnologica 54:14-22.

Green AJ, Sánchez MI, Amat F, Figuerola J, Hontoria F, Ruiz O, Hortas F, 2005. Dispersal of invasive and native brine shrimps Artemia (Anostraca) via waterbirds. Limnol. Oceanogr. 50:737-742.

Hawes I, 1985. Factors controlling phytoplankton populations in maritime Antarctic lakes, p. 245-252. In: W.R. Siegfried, P.R. Condy and R.M. Laws (eds.), Antarctic nutrient cycles and food webs. Springer, Berlin.

Heilmeier H, Durka W, Woitke M, Hartung W, 2005. Ephemeral pools as stressful and isolated habitats for the endemic aquatic resurrection plant Chamaegigas intrepidus. Phytocoenologia 35:449-468.

Herbst DB, 2006. Salinity controls on trophic interactions among invertebrates and algae of solar evaporation ponds in the Mojave Desert and relation to shorebird foraging and selenium risk. Wetlands 26:475-485.

Horváth Z, Vad CF, Vörös L, Boros E, 2013. The keystone role of anostracans and copepods in European soda pans during the spring migration of waterbirds. Freshwater Biol. 58: 430-440.

Hunt RJ, Matveev VF, 2005. The effects of nutrients and zooplankton community structure on phytoplankton growth in a subtropical Australian reservoir: An enclosure study. Limnologica 35:90-101.

Hutorowicz A, 2009. [Standardowe objętości komórek do szacowania biomasy wybranych taksonów glonów planktonowych wraz z określeniem sposobu pomiarów i szacowania]. [Article in Polish]. Instytut Rybactwa Śródlądowego w Olsztynie, Olsztyn.

Kawecka B, Eloranta PV, 1994. [Zarys ekologii glonów wód słodkich i środowisk lądowych]. [Outline of ecology of freshwater and terrestrial algae]. [Book in Polish]. PWN, Warsaw.

Kollár J, Fránková M, Hašler P, Letáková M, Pouličková A, 2015. Epiphytic diatoms in lotic and lentic waters - diversity and representation of species complexes. Fottea 15:259-271.

Ledón-Rettig CC, Pfennig DW, Crespi EJ, 2009. Stress hormones and the fitness consequences associated with the transition to a novel diet in larval amphibians. J. Exp. Biol. 212:3743-3750.

Levine SN, Borchardt MA, Braner M, Shambaugh A, 1999. The impact of zooplankton grazing on phytoplankton species composition and biomass in Lake Champlain (USACanada). J. Great Lakes Res. 25:61-77.

Lumbreras A, Marques JT, Belo AF, Cristo M, Fernandes M, Galioto D, Machado M, Mira A, Sá-Sousa P, Silva R, Sousa LG, Pinto-Cruz C, 2016. Assessing the conservation status of Mediterranean temporary ponds using biodiversity: a new tool for practitioners. Hydrobiologia 782:187-199.

Marrone F, Barone R, Naselli-Flores L, 2006. Ecological characterization and cladocerans, calanoid copepods and large branchiopods of temporary ponds in a Mediterranean island (Sicily, Southern Italy). Chem. Ecol. 22(Suppl.1):181-190.

Naceur HB, Jenhani ABR, Romdhane MS, 2011. Influence of environmental factors on the life cycle and morphology of Artemia salina (Crustacea: Anostraca) in Sabkhet El Adhibet (SE Tunisia). Biological Lett. 48:67-83.

Nival P, Nival S, 1976. Particle retention efficiencies of an herbivorous copepod, Acartia clausi (adult and copepodite stages): Effects on grazing. Limnol. Oceanogr. 21:24-38.

Peters RH, Downing JA, 1984. Empirical analysis of zooplankton filtering and feeding rates. Limnol. Oceanogr. 29:763-784.

Reynolds CS, 1984. The ecology of freshwater phytoplankton. Cambridge University Press, Cambridge: 384 pp.

Reynolds CS, 2006. Ecology of phytoplankton. Cambridge University Press, Cambridge: 535 pp.

von Rückert G, Giani A, 2008. Biological interactions in the plankton community of a tropical eutrophic reservoir: is the phytoplankton controlled by zooplankton? J. Plankton Res. 30:1157-1168.

Riisgård HU, Zalacáin D, Jeune N, Wiersma JB, Lüskow F, Pleissner D, 2015. Adaptation of the brine shrimp Artemia salina (Branchiopoda: Anostraca) to filter-feeding: effects of body size and temperature on filtration and respiration rates. J. Crustacean Biol. 35:650-658.

Seminara M, Vagaggini D, Stoch F, 2015. Long-term monitoring of astatic water bodies: microcrustaceans as indicators of hydroperiod length in ponds and pools. Rend. Fis. Acc. Lincei 26: 345-352.

Waterkeyn A, Grillas P, Vanschoenwinkel B, Brendonck L, 2008. Invertebrate community patterns in Mediterranean temporary wetlands along hydroperiod and salinity gradients. Freshwater Biol. 53:1808-1822.

Williams DD, 2006. The biology of temporary waters. Oxford University Press: 348 pp.

Vanderstukken M, Declerck SAJ, Pals A, de Meester L, Muylaert K, 2010. The influence of plant-associated filter feeders on phytoplankton biomass: A mesocosm study. Hydrobiologia 646:199-208.

Vinebrooke RD, Maclennan MM, Bartrons M, Zettel JP, 2014. Missing effects of anthropogenic nutrient deposition on sentinel alpine ecosystems. Glob. Change Biol. 20:2173-2182.

Zongo B, Zongo F, 2016. Microalgae community composition in tropical temporary freshwater ponds of Burkina Faso (West Africa). Am. J. Agr. Sci. 3:72-84. 